\title{
Human Rights in the Supply Chains of Australian Businesses: Opportunities for Legislative Reform Brynn O'Brien and Martijn Boersma
}

\section{BATMIUST 》 theAustralialnstitute \\ Research that matters.}

\section{Summary}

Australian businesses have recently been implicated in serious labour abuses, both within and beyond Australia's borders. Recent examples to capture public attention are slave labour in the production of surf products by Australian brands in North Korea ${ }^{1}$, human trafficking and labour exploitation in Vietnamese, Chinese and Thai fishing industries (the top suppliers of prawns to Australian retailers) ${ }^{2}$ and labour abuses in domestic fresh food supply chains ${ }^{3}$ and 7 -Eleven stores. ${ }^{4}$

In response to concerns about labour abuses and human rights violations in supply chains, a multi-stakeholder Working Group on Slavery in Supply Chains (Working Group), involving of representatives from government, civil society, industry and academia, was established in 2014 by Justice Minister the Hon Michael Keenan MP, following a Parliamentary Inquiry into Modern Slavery and Human Trafficking that commenced in 2012.

After an intensive program involving over 12 months of meetings, the Working Group has now been dissolved. Despite promises of swift consideration of the Working Group's efforts by the responsible Minister, the comprehensive report and recommendations remain confidential and had not been put to the Minister at the time of writing. Given the time, effort and expense invested by participants in the Working Group, the lack of government action is disappointing.

Meanwhile, other jurisdictions are experimenting with various forms of regulation, examples of which are described in this paper. While it is too early to evaluate in detail the efficacy of these measures, it is evident that the challenges of safeguarding human rights in supply chains are complex, and that responses will need to be refined over time. Australia should learn from measures taken in other jurisdictions and, in the face of urgent human rights issues and foreign legislative measures with immediate impacts for Australian companies, resist stagnating on reform.

While the Working Group's report remains confidential, this paper reflects in general terms on the progress and reform proposals made by the Working Group. This is done in the hope that such proposals will be taken up for consideration by legislators in the immediate future.

In this parliamentary term, the focus for Australian legislators should be on crafting a response with broad application and legislative teeth. Regulatory measures should address a range of human rights impacts by going beyond slavery and trafficking. This approach recognises that "business enterprises can have an impact on virtually the entire spectrum of internationally recognized human rights." 


\section{Introduction}

Supply chains - vertically integrated, contractual systems of production - are the primary economic vehicles through which contemporary global trade and commerce occurs ${ }^{6}$. They present unique and significant challenges for regulators, weakening the chain of legally enforceable responsibility for workplace abuses. This is emphasised in the transnational context, where there is a pattern of outsourcing of production by companies to jurisdictions where labour standards enforcement is weak.

In response to the prevalence of labour exploitation and human rights violations in global supply chains, a recent wave of legislative action has seen governments in the US and Europe consider various proposals aimed at building supply chain responsibility for companies operating (in whole or in part) within their jurisdictions. While this phase of transnational supply chain regulation is best described as experimental, the trends emerging from it provide valuable insights for legislative action in the Australian context.

The broader context for legislative developments is underpinned by the UN Guiding Principles on Business and Human Rights (UNGPs). ${ }^{7}$ Adopted in 2011, the UNGPs promulgate a new way of thinking about supply chain human rights impacts and responsibilities by introducing a non-prescriptive, fluid framework requiring companies to "know" their impacts, and "show" that they know.

The UNGPs are clear that responsibility for human rights impacts does not stop at direct impacts, but extends through the "value chain" to impacts "linked" to "operations, products or services" through "business relationships". ${ }^{8}$ The explicit linking of "products" and adverse human rights impacts grapples with the realworld problem of dissipation of the power of worker protections, envisaging a responsibility that extends through entire supply chains.

\section{Existing Australian regulation}

Specific industries in Australia have had success with supply chain transparency and disclosure regimes ${ }^{9}$. Both the textiles, clothing and footwear, and road transport sectors have been subject to mandatory statebased codes requiring lead firms in the supply chain to know and show certain things about their supply chains - relating, inter alia, to conditions of work, location of work, pay and safety for workers. Early studies of these initiatives have shown encouraging trends, with instances of exploitation decreasing as transparency requirements become more onerous. ${ }^{10}$

There is speculation that existing provisions in the Commonwealth Fair Work Act 2009 could be used for strategic interventions where abuses are identified in supply chain context. Section 550 of the Fair Work Act provides for liability where someone is "involved in a contravention of [relevant provisions dealing with workplace protections]" including through being "knowingly concerned in or party to the contravention". ${ }^{11}$ Janine Webster, Chief Counsel at the Office of the Fair Work Ombudsman (FWO), commented in the Australian Financial Reviewin May on the possibility that:

"Irrespective of whether or not a business employs someone directly, irrespective of whether or not they're a contractor or hold some other form of relationship, the business has a responsibility to ensure workers are receiving proper wages and other entitlements under the Fair Work Act...[an individual or corporate entity who] is involved in a contravention can be treated the same as the person who actually committed the contravention..."12

While this paper's review did not identify any reported cases in which the application of s550 has been tested in a supply chain context, Ms Webster indicated that the FWO has investigated such circumstances: 
"More and more we are looking to see who was involved in a contravention as well as the employer, in order to join them together and to have the imposition of penalties made against them as well."13

Novel applications of this provision in cases of supply chain exploitation could enhance accountability efforts.

\section{Recent federal government initiatives}

While senior members of government across Labor and Liberal parties have expressed an intention to address issue of slavery in supply chains, a pattern of inaction is discouraging. That is, while a commitment to addressing the issue, enjoying apparent bipartisan support, has been made, it has not yet brought regulatory action. Further, the federal government's approach to addressing the issue within its own procurement processes is underdeveloped at best.

In March 2013, then Prime Minister Julia Gillard announced a "whole of government strategy [to improve] procurement arrangements by:

- Processes: the Department of Finance and Deregulation will ensure that Commonwealth procurement arrangements adequately identify slavery as an important issue when considering the ethical behaviour of suppliers.

- Advice to Agencies: the Department of Finance and Deregulation will issue revised procurement guidance to reinforce the need for specific actions or behaviours to eliminate the chances of slavery being used in supply chains.

- Training: the Department of Finance and Deregulation will strengthen training and development arrangements for Commonwealth procurement officers to reinforce specific legal and policy requirements, including reporting of breaches of policy. ${ }^{14}$

It is unclear to what extent these commitments were ever followed up with action. Federal procurement rules require Commonwealth officers to act "ethically" ${ }^{15}$ and in 2014 the Attorney-General's Department distributed an "information sheet" to Commonwealth procurement officers with a focus on human trafficking. ${ }^{16}$ This however is best viewed as an awareness raising strategy, and did not set out any enforceable responsibility on Commonwealth officers in respect of procedures to identify or avoid adverse human rights impacts in the supply chain.

The 2015-2019 National Action Plan to Combat Human Trafficking and Slavery, released in December 2014, identifies the Government's "response to labour exploitation in supply chains" as a key focus area. ${ }^{17}$

In 2014, the Minister for Justice, the Hon Michael Keenan MP, established the Working Group on Slavery in Supply Chains, with the aim of providing expert input on the best ways to deal with slavery and human trafficking in the supply chains of Australian companies. ${ }^{18}$ Given that the report of the Working Group has not been made public at the time of writing, it is worth detailing the time and effort that went into preparing it:

- The first meeting was held in November 2014, and the final meeting was held in December 2015. In total, eight meetings were held, each of at least half a day, in Sydney, Canberra and Melbourne.

- Attendance at these meetings was in general over 15 participants, at the expense of organisations which presumably saw an opportunity for genuine attention to an urgent issue. In airfares alone, the cost for each meeting would easily have exceeded $\$ 5000$.

- The group comprised over 20 representatives from government, civil society, academia and the private sector. 
- A suite of detailed, costed recommendations, from the adoption of mandatory disclosure measures similar to the UK Modern Slavery Act, to incentivising good conduct by business through an awards scheme, were delivered in December 2015. ${ }^{19}$

- Given their central role under Gillard's 2013 proposals, it is worth noting that the Department of Finance discontinued its participation in the Working Group before preparation of the group's report.

- In May 2016, Working Group members received an email advising them that government had not yet considered the report and that, as the Government was in caretaker period the report would not be considered until a new Government was formed.

In summary, while calls for the Australian government to address human rights abuses in the supply chains of Australian companies have been repeated since at least 2013, the government has taken no regulatory action in response.

Two current processes being led by the Department of Foreign Affairs and Trade - the Roundtable on Transparency in Extractives and a nascent consultation on a National Action Plan on Business and Human Rights - will involve consideration of human rights issues in a supply chain context. It is unclear whether efforts will be made to integrate the report and recommendations of the Working Group with these processes.

\section{Legislative and regulatory developments abroad}

\section{(a) USA}

In contrast, lawmakers in the USA have experimented in the last five years with various supply chain accountability and reporting measures. Overall, US lawmaking has been narrowly tailored to address priority issues, and has not aimed for a universal response.

The Dodd-Frank Wall Street Reform and Consumer Protection Acto (Dodd-Frank) contains "conflict minerals" provisions, aimed at preventing US companies' complicity in the conflict in the Democratic Republic of the Congo via their commercial interests in the trade of minerals, and preventing human rights abuses connected to that trade. ${ }^{21}$ The Dodd-Frank conflict minerals provisions came into effect in November $2012 .{ }^{22}$

Under Dodd-Frank companies are required to undertake due diligence processes and publicly report on the level of traceability of their supply chains, where minerals have originated the Democratic Republic of the Congo or adjacent countries." ${ }^{23}$ An early evaluation of the program has noted encouraging progress in terms of forcing companies to look deep into their supply chains, ${ }^{24}$ though critics have pointed to problems inherent in 'top-down' regulation such as lack of consultation with affected communities, ${ }^{25}$ and difficulties in verifying conditions and the chain of custody on the ground. ${ }^{26}$

The State of California legislated in 2010 through the California Transparency in Supply Chains Act of $2010^{27}$ (California TSCA) effective as of 1 January 2012, to require companies of $\$ 100$ million gross worldwide receipts doing business in California to "disclose [their] efforts to eradicate slavery and human trafficking from [their] direct supply chain[s] for tangible goods offered for sale," so that consumers might make better purchasing decisions. Under this law, companies are required to report publicly on their efforts, but are not obliged to undertake any particular activities.

Critics of the scheme have highlighted that the law "does not require that the names of the companies subject to [it] be made public, leaving both consumers and corporations unaware of which businesses are subject to the law. This lack of information hinders the law's ability to achieve true transparency and disseminate 
information at the scale it had originally intended."28 The effectiveness of the law is further hampered by the wide variation in corporate responses and the lack of effective sanctions for inadequate reporting. ${ }^{29}$

In September 2012, President Barack Obama announced an Executive Order requiring US Federal government contractors with contracts in excess of $\$ 500 \mathrm{~m}$ value to take measures to ensure that their supply chains are free of human trafficking and slavery. ${ }^{30}$ Because of the US government's status as the largest purchaser in the global economy, the Executive Order has far-reaching implications. This measure comes with the added benefit of monitoring and enforcement by US officials, and the threat of commercial sanctions for companies that do not comply. It has been described as "best practice in regards to governmental selfregulation." 31

\section{(b) Europe}

A range of measures promoting supply chain transparency and corporate responsibility are in operation in Europe, and a further raft of legislative proposals are currently under consideration by both national and European legislative bodies. In addition, various European national governments have adopted National Action Plans on Business and Human Rights and a further cohort are currently in the process of consultation towards adoption of a plan, or are undertaking National Baseline Assessments. ${ }^{32}$

In 2015 the United Kingdom passed supply chain transparency legislation in Part 6 of the Modern Slavery Act 2015. ${ }^{33}$ This legislation is similar in character to the California TSCA, requiring disclosure by companies of their efforts to identify slavery and human trafficking in their supply chains, and giving examples of what those efforts might look like, but not obliging any particular efforts other than a statement of what they have done. Importantly, this legislation applies to companies of annual gross worldwide revenues of $£ 36$ million that do any part of their business in the UK (including many Australian companies ${ }^{34}$ ).

In Denmark, Section 99a of the Danish Financial Statements Act ${ }^{35}$ provides mandatory policy disclosure requirements. Businesses covered by the Danish rules (approximately 1,100 large businesses in total) are not obliged to undertake any specific corporate social responsibility (CSR) activities, but are required to report on any CSR policies (including, via a 2013 amendment, on human rights policies). The most recent Danish Government study of the impact of this legislation showed that $96 \%$ of companies surveyed complied with the reporting requirement, with $77 \%$ of those companies disclosing a CSR policy, and $66 \%$ disclosing a human rights policy. ${ }^{36}$

At EU level, the 2012 directive on non-financial reporting requires States to implement legislation in order to require 'public interest entities' (listed companies, banks, insurance undertakings and other companies as designated in national regulations) with more than 500 employees within their jurisdiction to report on various non-financial impacts of their activities and supply chains - including on human rights, as well as their efforts at identifying and preventing risks. ${ }^{37}$ This directive is in a transitional phase and is expected to be implemented by national governments by late 2016 (with national transitions to follow).

The European Parliament voted in May 2015 in favour of a strengthened proposal on the traceability and mandatory monitoring of supply chains that involve conflict minerals, a measure that will affect an estimated 800,000 European companies. ${ }^{38}$

A trend towards requiring companies to undertake mandatory and broad human rights due diligence is reflected in proposals currently before French ${ }^{39}$ and Swiss ${ }^{40}$ legislators as well as in a motion passed by the European Parliament in April 201541, however, each of these proposals still faces significant hurdles in order to become law. ${ }^{42}$ 


\section{Legislative typology}

There is a variation in emphasis among legislative approaches to human rights issues in supply chains, and no definitive standard has emerged. The legislative schemes reviewed above can be classified by their mechanism and by the type of human rights impact targeted by the measure.

\section{Schemes by mechanism: \\ Reporting and disclosure: companies are required to report on the policies they have in place (whether or not they have any policy in place in place) and/or the activities they have undertaken (whether or not there is an obligation to undertake any action).}

\section{Schemes by target impact:}

Human rights impacts: a broad range of human rights impacts are relevant. This approach can take into account extreme labour abuses (slavery and trafficking), displacement, abuses by security forces, etc. These approaches generally sit under the framework of the UNGPs and have been favoured in recent European initiatives.

Labour standards: the full range of labour standards are relevant, including health and safety, wages, discrimination, collective action and extreme labour abuses.
Due diligence and risk profiling: companies are required to undertake human rights due diligence or say whether they have undertaken human rights due diligence. This can be a general requirement or associated with risk profiling.
Visibility and transparency: companies are required to have visibility over certain parts of their supply chains, to disclose or have the ability to disclose parts of their supply chains (to the public, to regulators, or to an independent verification body), or to disclose whether they have visibility over certain parts of their supply chains.

Origin and traceability: companies are required to know the origin and/or chain of custody of components of their products (conflict minerals legislation). Traceability legislation commonly involves some sort of due diligence, or a requirement to show whether due diligence has been undertaken, and some type of independent verification.
Slavery, forced labour and human trafficking: only extreme labour abuses are taken into account.
Conflict minerals: these approaches situate human rights abuses in a geographical, political and rule of law context.

\section{Conclusion and recommendations}

The Australian government must step up its efforts to eliminate human rights abuses in the supply chains of Australian businesses, as well in its own supply chains. The recommendations of the Working Group on Slavery in Supply Chains must be considered, responded to and made publicly available by the Justice Minister, considering the recommendations were delivered to the government over nine months ago. 
Given the Australian government's broader consideration of human rights impacts in supply chains, not only through the Working Group but also through DFAT's activities on extractives and a National Action Plan on Business and Human rights, it is the authors' view that the best legislative response at this point would target a range of adverse impacts, adopting the "human rights" framing.

Two measures should be adopted as a first step, however, regardless of the breath of the impacts targeted.

Firstly, the government should legislate for mandatory disclosure by companies of the steps taken to identify adverse human rights impacts in their supply chains. As discussed above, reporting requirements are the central regulatory mechanism that can help to mitigate the risk of human rights abuses in supply chains. Determining what companies ought to disclose is a longer conversation, and the authors favour a model which encourages companies to have visibility over their supply chains, especially in high-risk industries. Guidance on how companies should undertake due diligence would enhance this response.

Secondly, the government should strengthen its own procurement processes to identify and mitigate the adverse impacts of its purchasing decisions. Government procurement at the local, State and Federal level is connected to potential human rights abuses in high-risk supply chains. As a large purchaser in the Australian economy, decisions and processes of government at all levels have an impact. In the style of the Obama Administration's Executive Order, the Australian Government should update its procurement and tender policies to require significant suppliers and contractors to undertake measures to ensure that the goods and services the government purchases are free of human trafficking and slavery. While this recommendation is specifically targeted at the federal government, state and local governments would also benefit from enforceable codes.

These steps would bring Australia into line with comparable countries' progress over the last five years, and position Australian companies alongside their peers in the global economy.

\footnotetext{
${ }^{1}$ Nick McKenzie and Richard Baker, Where Your Ski Jacket Really Comes from (21 February 2016) The Sydney Morning Herald <http://www.smh.com.au/business/surf-clothing-label-rip-curl-using-slave-labour-to-manufacture-clothes-in-no rth-korea20160219-gmz375.html>.

2 Greenpeace Report: Dodgy Prawns Greenpeace Australia Pacific <http://www.greenpeace.org/australia/en/what-wedo/oceans/resources/reports/Dodgy-Prawns />.

3 Slaving Away (4 May 2015) <http://www.abc.net.au/4corners /stori es/2015/05/04/4227055.htm>.

4 7-Eleven: The Price of Convenience (30 August 2015)

<http://www.abc.net.au/4corners/stories /2015/08/30/4301164.htm>.

${ }^{5}$ John Ruggie, 'UN Guiding Principles on Business and Human Rights: Implementing the United Nations "Protect, Respect and Remedy" Framework' commentary to Guiding Principle 12.

${ }^{6}$ See, for example, International Trade Union Confederation, 'Scandal: Inside the Global Supply Chains of 50 Top Companies' (ITUC Frontlines Report, 2016) <http://www.ituc-csi.org/IMG/pdf/pdffrontlines_scandal_en-2.pdf> at 4-5.

${ }^{7}$ Ruggie, above $\mathrm{n} 5$.

8 Ibid Guiding Principle 13(b).

${ }^{9}$ Ethical Clothing Trades Extended Responsibility Scheme 2005 (NSW); Fair Work (Clothing Outworker Code of Practice) Regulations 2007 (SA)

10 See Michael Rawling, 'Legislative Regulation of Global Value Chains to Protect Workers: A Preliminary Assessment' [2015] The Economic and Labour Relations Review 1035304615615513; Michael Rawling and Sarah Kaine, 'Regulating Supply Chains to Provide a Safe Rate for Road Transport Workers' (2012) 25(3) Australian Journal of Labour Law 237; Richard Johnstone, Igor Nossar and Michael Rawling, 'Regulating Supply Chains to Protect Road Transport Workers: An Early Assessment of the Road Safety Remuneration Tribunal' (2015) 43 Fed. L. Rev. 397; Igor Nossar et al, 'Protective Legal Regulation for Home-Based Workers in Australian Textile, Clothing and Footwear Supply Chains' (2015) 57(4) Journal of Industrial Relations 585.

11 S550 Involvement in contravention treated in same way as actual contravention
}

(1) A person who is involved in a contravention of a civil remedy provision is taken to have contravened that provision. 
(2) A person is involved in a contravention of a civil remedy provision if, and only if, the person:

(a) has aided, abetted, counselled or procured the contravention; or

(b) has induced the contravention, whether by threats or promises or otherwise; or

(c) has been in any way, by act or omission, directly or indirectly, knowingly concerned in or party to the contravention; or

(d) has conspired with others to effect the contravention.

12 May 52015 at 2:40 PM and Updated May 52015 at 8:18 PM, Workplace Watchdog Aims for Top of Retailers' Supply Chain on Worker Exploitation (5 May 2015) Financial Review <http://www.afr.com/business/retail/workplace-watchdog-aims-fortop-of-retailers-supply-c hain-on-work er-exploitation-20150504-ggu5pl>.

13 Ibid.

14 Transcript 19141 / PM Transcripts <https://pmtranscripts.dpmc.gov.au/release/transcript-19141>.

152014 Commonwealth Procurement Rules.pdf <http://www.finance.gov.au/sites/default/files/2014\%20Co mmonwealth\%2 0Procurement\%20Rules.pdf>.

16 Human Trafficking Information Sheet for Commonwealth Government Procurement Officers - Human-Trafficking-InformationSheet-for-Commonwealth-Government-Procurement-Officers.pdf

<https://www.ag. gov.au/CrimeAnd Corruption/Hum anTrafficking/Documents/Human-T rafficking-Information-sheet-forCommonwealth-Governm ent-p rocurem ent-offic ers.pdf>.

17 National Action Plan to Combat Human Trafficking and Slavery 2015-19 - TraffickingNationalActionPlanToCombatHumanTraffickingAndSlavery2 015-19.pdf

$<$ https://www.ag. gov.au/CrimeAndCor ruption/HumanTrafficking/Documents/Trafficking-

NationalActionPlanToCombatHum anT raffickingAndSlav ery2 015 -19.pdf $>$.

18 Working Group's Terms of Reference, November 2014

${ }^{19}$ Ashley Feasley, 'Deploying Disclosure Laws to Eliminate Forced Labour: Supply Chain Transparency Efforts of Brazil and the United States of America' (2015) 0(5) Anti-Trafficking Review

$<\mathrm{http} / / /$ www.antitraffickingreview.org/index.php/atrjournal/article/view/135>.

20 Dodd-Frank Wall Street Reform and Consumer Protection Act (Pub.L. 111-203, H.R. 4173).

21 Final Rule: Conflict Minerals - 34-67716.pdf <https://www.sec.gov/rul es/final/2012/34-67716.pdf>.at page 8 "to accomplish the goal of helping end the human rights abuses in the DRC caused by the conflict, Congress chose to use the securities laws disclosure requirements to bring greater public awareness of the source of issuers' conflict minerals and to promote the exercise of due diligence on conflict mineral supply chains. By doing so, we understand Congress's main purpose to have been to attempt to inhibit the ability of armed groups in the Covered Countries to fund their activities by exploiting the trade in conflict minerals.

Reducing the use of such conflict minerals is intended to help reduce funding for the armed groups contributing to the conflict and thereby put pressure on such groups to end the conflict."

22 Ibid.

23 Ibid.

${ }^{24}$ Enough Project, What Happens to A Dream Deferred? The Impact of Dodd-Frank and Conflict Minerals Reforms on Eastern Congo's Conflict (10 June 2014) <http://www.eno ughproject.org/files/Enough\% 20 Pro ject $\% 20$ -

\%20The\%20Impact\%20of\%20Dodd-

Frank\%20and\%20Conflict\%2 0Minerals\%20Reforms\%20on\%20Eastern\%20Congo\%E2\% 80\%99s\%20Conflict\%2010June2 014.pdf>.

${ }^{25}$ Lauren Wolfe, 'How Dodd-Frank Is Failing Congo' <https://foreignpolicy.com/2015/02/02/how-dodd-frank-is-failingcongo-mining-conflict-minerals/>.

${ }^{26}$ Emily Chasan, “'Conflict Minerals" Too Hard to Track, Commerce Department Says' Wall Street Journal, 5 September 2014 <http://www.wsj.com/articles/conflict-minerals-prove-hard-to-track-1409951193>.

27 section 1714.43 of the California Civil Code

${ }^{28}$ KnowTheChain, 'SB 657 Five Years of the California Transparency in Supply Chains Act' <https://knowthechain.org/insights-brief/>. See also Jonathan Todres, "Why California Transparency Law Isn"t so Transparent" CNN.com, 16 June 2015 <http://edition.cnn.com/2015/06/16/opinions/california-transparency-supplychains-law-trafficking/>.

${ }^{29}$ Feasley, above $\mathrm{n} 20$.

30 White House, Executive Order - Strengthening Protections Against Trafficking In Persons In Federal Contracts (25 September 2012) whitehouse.gov <https://www.whitehouse.gov/the-press-office/2012/09/25/executive-order-strengtheningprotections-against-trafficking-persons-fe>.

31 Feasley, above n 20. 
32 Office of the High Commissioner for Human Rights, State National Action Plans

<http://www.ohchr.org/EN/Issues/Business/Pages/NationalActionPlans.aspx>. National Baseline Assessments gauge how far current law, policy, and other measures at the national level give effect to the State's duty to protect human rights under the UNGPs and other international business and human rights standards. In general, such an assessment is conducted at the start of an intervention. The results can then be used to assess impact and to compare future conditions with the initial status after a particular intervention or program has been implemented. It offers a standardized approach to business and human rights baseline analysis across countries. See http://icar.ngo/wp-content/uploads/2015/03/ICAR-Shadow-U.S.NBA-Pillar-1.pdf

33 Modern Slavery Act 2015 (UK), section 54

${ }^{34}$ Abigail McGregor, Challenges for Australian Businesses Arising from Modern Slavery Legislation $<$ http://www.no rto nrosefulbright.com/knowledge/publications /126258/challenges-for-australian-businesses-arisingfrom-modern-slavery-legislation>.

35 Introduced by the Act amending the Danish FinancialStatement Act (Accounting for CSR in large businesses) 2008

${ }^{36}$ Danish Government, CSR office, 'Financial Year Report 2013 - Executive Summary' $<$ http://csrgov.dk/file/536161/executive_summary_report_financiel_year_2013.pdf>.

${ }^{37}$ Non-Financial Reporting - European Commission <http://ec.europa.eu/finance/company-reporting/non-

financial_reporting/index_en.htm>.

${ }^{38}$ EurActiv and part of the Guardian development network, 'European Parliament Votes for Tougher Measures on Conflict Minerals' The Guardian, 21 May 2015 <https://www.theguardian.com/global-development/2015/may/21/europeanparliament-tough er-measures-conflict-minerals>.

${ }^{39}$ Assemblée nationale, Assemblée Nationale - Entreprises: Devoir de Vigilance Des Entreprises Donneuses D'ordre $<\mathrm{http} / /$ www.assembl ee-nationale.fr/14/dossiers/devoir_vigilance_entreprises_donneuses_ordre.asp>.

40 Berne Declaration, Press Release - Berne Declaration (21 April 2015) <https://www.bernedeclaration.ch/de/media/press release/press/global_business_global_responsibility/>.

${ }^{41}$ Arnaud Poitevin, The EU May Move towards Mandatory Business \& Human Rights Regulation (9 May 2015) LinkedIn Pulse $<$ https://www.linkedin.com/pulse/eu-moves-towards-mandatory-business-hum an-rights-arnaud-poitevin>.

42 See, for example, Arnaud Poitevin, Mandatory Human Rights Due Diligence : Government 1, Devoir de Vigilance 0 (12 March 2016) LinkedIn Pulse <https://www.linkedin.com/pulse/mandatory-human-rights-due-diligence-government-1-devoir-poitevin>. 